biparietal diameter between 12 and 30 weeks indicates maturity to within acceptable limits. ${ }^{6}{ }^{8}$ Most clinical decisions concerning delivery must be made after 30 weeks, however, and if an ultrasound scan has not been performed then $x$-ray examination or amniocentesis is clearly justified. If results of a previous scan are available then the case for performing an $x$-ray examination is weaker.

The appreciable reduction in the proportion of patients $x$ rayed since the ultrasound service was introduced at our centre is probably at least partly attributable to the clinical acceptance of ultrasound measurements. The use of the lecithin: sphingomyelin ratio in assessing fetal lung maturity may also have contributed, but this necessitates amniocentesis, which is associated with appreciable morbidity ${ }^{9-12}$ and mortality, Goodlin and Clewell having reported sudden fetal death and Kirshen and Benirschke fetal exsanguination after amniocentesis. ${ }^{13} 14$ In our series one fetal death occurred and two emergency caesarean sections were carried out for fetal distress immediately after amniocentesis to determine the lecithin:sphingomyelin ratio. All three patients had had anterior placentas detected by ultrasound, and the amniocenteses were not performed under ultrasound control. The most common reason for requesting $x$-ray examination was to estimate maturity, and in our series these estimates agreed with previous ultrasound estimates to within less than two weeks in two-thirds of cases. In the onethird in which there was disagreement the ultrasound measurements were relied on far more heavily than the estimates obtained by radiography. Of the 130 cases in which both examinations were carried out, in only four were the $x$-ray findings accorded greater clinical value. In three of these reliance on the ultrasound findings would have indicated induction about one week before spontaneous labour occurred and been unlikely to influence fetal outcome. We therefore think that a satisfactory ultrasonic measurement before 30 weeks' gestation-that is, a BPD less than $80 \mathrm{~mm}$-obviates the need for subsequent estimation of maturity by $x$-ray examination.
If ultrasound is available $x$-ray examination is not justifiable for diagnosing twins or fetal position but is probably still justifiable for diagnosing fetal abnormalities. This and the value of routine radiography of twins, however, are the subjects of separate studies.

Routine ultrasound examination in early pregnancy already permits the diagnosis of twins, anencephaly, spina bifida, hydatidiform mole, etc. If a reduction in the exposure to $x$-rays of mother and fetus is considered to be an end in itself, perhaps this is a further indication for ultrasonic screening of all early pregnancies.

\section{References}

${ }^{1}$ Buchanan, R A, Finkelstein, S T, and Wickesheim, K A, Radiology, 1972, $105,185$.

2 Ardran, G M, Langmead, W A, and Crooks, H E, British fournal of Radiology, 1975, 48, 233.

${ }^{3}$ Pritchard, C, and Hufton, A, Radiography, 1976, 42, 14.

4 United Nations Scientific Committee on the Effects of Atomic Radiation, Report, vol 2. New York, United Nations, 1972.

5 Du Boulay, E P G H, fournal of the Royal College of Physicians of London, 1977, 11, 255.

${ }^{6}$ Campbell, S, Fournal of Obstetrics and Gynaecology of the British Commonwealth, 1969, 76, 603.

${ }^{7}$ Carmichael, J H E, and Berry, R J, Lancet, 1976, 1, 351.

${ }^{8}$ Robinson, H P, British Medical fournal, 1973, 4, 28.

9 Grove, C S, Trombetta, G C, and Amstey, M S, American fournal of Obstetrics and Gynecology, 1973, 115, 1154.

${ }^{10}$ Bartsch, F K, Lundberg, J, and Wahlstrom, J, fournal of Obstetrics and Gynaecology of the British Commonwealth, 1974, 81, 991.

11 Harrison, R, Campbell, S, and Craft, I, Obstetrics and Gynecology, 1975, 46, 389.

12 Rome, R M, Glover, J C, and Simmons, S C, British fournal of Obstetrics and Gynaecology, 1975, 82, 662.

${ }^{13}$ Goodlin, R C, and Clewell, W H, American fournal of Obstetrics and Gynecology, 1974, 118, 285.

14 Kirshen, E J, and Benirschke, K, Obstetrics and Gynecology, 1973, 42, 615.

(Accepted 18 fanuary 1978)

\title{
High-density and low-density lipoproteins and prevalence of vascular disease in diabetes mellitus
}

\author{
J P D RECKLESS, D J BETTERIDGE, P WU, B PAYNE, D J GALTON
}

British Medical fournal, 1978, 1, 883-886

\section{Summary and conclusions}

The prevalence of vascular disease among 154 diabetic patients was analysed in relation to the serum concentrations of individual lipoproteins. Overall the presence of vascular disease ( 59 cases) was positively associated with serum cholesterol and low-density-lipoprotein cholesterol but negatively associated with high-density-

\footnotetext{
Diabetes and Lipid Research Laboratory, St Bartholomew's Hospital, London EC1A 7BE

J P D RECKLESS, MD, MRCP, research fellow (present address: Royal Hospital, Sheffield)

D J BETTERIDGE, BSC, MRCP, research fellow

$P$ WU, BA, biochemist

B PAYNE, MA, biochemist

D J GALTON, MD, FRCP, consultant physician
}

lipoprotein (HDL) cholesterol. The negative relation between HDL and vascular disease was not observed in all subgroups of diabetics. We conclude that there may be no overriding association between HDL and vascular disease in diabetics as proposed for some non-diabetic populations.

\section{Introduction}

Recent studies have suggested that high-density lipoprotein (HDL) may protect against coronary artery disease. Thus population surveys have shown inverse relations, independent of other risk factors, between HDL-cholesterol concentrations and the prevalence of coronary artery disease. ${ }^{1-5}$ Furthermore, patients with ischaemic heart disease have significantly lower concentrations of HDL in serum than healthy people. ${ }^{6-10}$ Glomset $^{11}$ postulated that HDL exerts its protective effect by promoting cholesterol efflux from the arterial wall. Some support for this was provided when the apoproteins of HDL were found to enhance the efflux of cholesterol from aortic smooth-muscle cells in tissue culture. ${ }^{12}$ Another possibility is 
that HDL interacts with low-density lipoproteins (LDL), so reducing their binding, uptake, and degradation by fibroblasts and arterial cells. ${ }^{13-15}$

Patients with diabetes mellitus commonly develop premature and extensive atherosclerosis. ${ }^{16-19}$ Diabetic patients also have an increased prevalence of raised serum cholesterol and triglyceride concentrations. ${ }^{19-22}$ Because lipoprotein concentrations had not been extensively studied in diabetic populations we decided to measure the concentrations of HDL, LDL, and very-low-density lipoproteins (VLDL) in relation to the prevalence of vascular disease to see if HDL is inversely related to the prevalence of atheroma.

\section{Patients and methods}

One hundred and fifty-four patients attending the diabetic clinic were examined for the presence of vascular complications and lipoprotein abnormalities. The patients were a cohort of diabetics who had been followed up prospectively since 1963.

The presence of large-vessel disease was determined by several criteria. Previous myocardial infarction was recorded when there was an appropriate clinical history together with positive electrocardiographic and cardiac enzyme evidence. Angina pectoris was assessed by the interviewing physician $(80 \%$ of interviews were conducted by JPDR or DJB). A positive history was recorded when the patient experienced recurring attacks of typical exertional anterior chest pain, usually with radiation, that were relieved by rest or nitroglycerin. Most such patients had supportive electrocardiographic changes. A documented history or evidence of a previous cerebrovascular accident was recorded. Pain in the leg muscles when walking, especially the calves, that disappeared with rest was considered to be intermittent claudication. Loss of limb pulses was recorded.

Table I compares the clinical details of the patients $(a)$ who were and were not dependent on insulin, and $(b)$ who had and did not have vascular disease. The men had a lower mean systolic blood pressure than the women $(140 \pm S E 1.7 \mathrm{~mm} \mathrm{Hg}$ compared with $151.8 \pm 2.6$ $\mathrm{mm} \mathrm{Hg} ; \mathrm{P}<0 \cdot 001)$, smoked more cigarettes daily $(9 \cdot 1 \pm 1.3$ compared with $5 \cdot 2 \pm 1 \cdot 1 ; \mathrm{P}<0.05)$, and drank more alcohol.

Blood was taken for lipoprotein analysis after a 14-hour fast. Serum lipoproteins were analysed by precipitation techniques. VLDL was precipitated from $1 \mathrm{ml}$ serum in glass tubes by adding $75 \mu 110 \%$ sodium dodecyl sulphate in $0.15 \mathrm{M}$ sodium chloride (SDS). After two hours of incubation at $35^{\circ} \mathrm{C}$ the tubes were centrifuged in an angle- head rotor for 20 minutes at $10000 \mathrm{~g}$. The soluble infranatant was removed without disturbing the floating VLDL precipitate. The tube but not the VLDL pellet was washed with $0 \cdot 1 \%$ SDS. The pellet was dissolved in $1 \mathrm{ml} 1 \% \mathrm{SDS}$ at $35^{\circ} \mathrm{C}$ and an aliquot extracted in isopropanol for measurement of VLDL-triglyceride and VLDLcholesterol. ${ }^{23}$

Chylomicrons, VLDL, and LDL were precipitated from $1 \mathrm{ml}$ serum at $0^{\circ} \mathrm{C}$ with use of heparin $(250$ units in $50 \mu \mathrm{l})$ and manganese chloride $(50 \mu 11 \mathrm{M}$ solution). HDL-cholesterol was measured in the supernatant. ${ }^{24}$ LDL-cholesterol was obtained by subtracting the sum of HDL and VLDL values from the total serum cholesterol.

Cholesterol and triglyceride concentrations were measured by semiautomated fluorometric techniques, Technicon method N77 and Liebermann-Burchard's reagent being used for cholesterol, and Cramp and Robertson's method ${ }^{25}$ being used for triglyceride. Lipoprotein-cholesterol and lipoprotein-triglyceride values obtained by precipitation techniques have been shown to be closely correlated with those obtained by preparative ultracentrifugation, ${ }^{23}{ }^{24}$ and we obtained similar results.

Expression of results-Results are expressed as the prevalence of vascular disease in the upper two quintiles (upper $40 \%$ ) and lower two quintiles (lower $40 \%$ ) of the distribution of each lipid and lipoprotein class. Significance of differences between quintiles was assessed with the $\chi^{2}$ test, Yates's correction being applied for continuity. Data were also examined by the Mann-Whitney U test.

\section{Results}

Table II gives the mean serum cholesterol, triglyceride, and lipoprotein concentrations (a) separately for men and women, and (b) for all patients who either needed or did not need insulin. Those not treated with insulin had significantly higher mean VLDL and LDL concentrations and a lower mean HDL concentration.

Altogether 59 patients $(38.3 \%$ ) had vascular disease (table I). Its prevalence in the lower two and upper two quintiles for each lipid and lipoprotein class is shown in table III. LDL-cholesterol was more strongly related to the prevalence of vascular disease than was HDLcholesterol. Interestingly patients in the upper quintiles for serum triglyceride and VLDL-triglyceride tended to have an increased prevalence of vascular disease, although the prevalences were not significantly different from those in the lower two quintiles. To minimise the possibility of observer error patients in whom the only evidence of vascular disease was loss of foot pulses were transferred to the group without vascular disease. The prevalences of vascular

TABLE I-Clinical details of patients (a) who were and were not dependent on insulin, and (b) who had and did not have vascular disease. Values are means \pm SE of mean

\begin{tabular}{|c|c|c|c|c|c|c|}
\hline & \multirow{2}{*}{$\underset{\text { (years) }}{\text { Age }}$} & \multirow{2}{*}{$\begin{array}{c}\text { Duration of } \\
\text { diabetes } \\
\text { (months) }\end{array}$} & \multirow{2}{*}{$\begin{array}{c}\% \text { Desirable } \\
\text { weight } \\
\left(\text { see ref }{ }^{27} \text { ) }\right.\end{array}$} & \multicolumn{2}{|c|}{ Blood pressure $(\mathrm{mm} \mathrm{Hg})$} & \multirow{2}{*}{$\begin{array}{c}\text { No of } \\
\text { cigarettes } \\
\text { daily† }\end{array}$} \\
\hline & & & & Systolic & Diastolic & \\
\hline $\begin{array}{l}\text { Insulin-dependent ( } 55 \text { men, } 51 \text { women }) \\
\text { Insulin-independent ( } 24 \mathrm{men}, 24 \text { women })\end{array}$ & $\begin{array}{l}55 \cdot 0 \div 1 \cdot 4 \\
67 \cdot 3 \pm 1 \cdot 2\end{array}$ & $\begin{array}{l}297 \cdot 9+10 \cdot 7 \\
226 \cdot 1 \div 10 \cdot 2\end{array}$ & $\begin{array}{l}113 \cdot 0 \pm 1 \cdot 3 \\
118 \cdot 0 \pm 3 \cdot 5\end{array}$ & $\begin{array}{l}140 \cdot 8 \pm 1 \cdot 8 \\
156 \cdot 7 \pm 2 \cdot 6\end{array}$ & $\begin{array}{l}83 \cdot 1 \pm 0 \cdot 8 \\
89 \cdot 5 \pm 1 \cdot 1\end{array}$ & $\begin{array}{l}7 \cdot 38 \pm 1.06 \\
6.75 \pm 1.53\end{array}$ \\
\hline Significance of difference $(\mathbf{P})^{*}$ & $<0.001$ & $<0.001$ & NS & $<0.001$ & $<0.001$ & NS \\
\hline $\begin{array}{l}\text { With vascular disease ( } 31 \text { men, } 28 \text { women) } \\
\text { Without vascular disease }(51 \text { men, } 44 \text { women) }\end{array}$ & $\begin{array}{l}65 \cdot 5 \pm 1 \cdot 1 \\
54 \cdot 7 \pm 1 \cdot 6 \\
\end{array}$ & $\begin{array}{l}296 \cdot 2 \pm 15 \cdot 8 \\
262 \cdot 7 \pm 27 \cdot 0 \\
\end{array}$ & $\begin{array}{l}120 \cdot 9 \pm 2 \cdot 4 \\
110 \cdot 6 \pm 1 \cdot 6\end{array}$ & $\begin{array}{l}154 \cdot 8 \pm 2 \cdot 5 \\
140 \cdot 2 \pm 1 \cdot 9 \\
\end{array}$ & $\begin{array}{l}86 \cdot 1 \pm 1 \cdot 9 \\
84 \cdot 4 \pm 0 \cdot 3\end{array}$ & $\begin{array}{l}7 \cdot 87 \pm 1.45 \\
6 \cdot 75 \pm 1.09\end{array}$ \\
\hline Significance of difference $(P)^{*}$ & $<0.001$ & NS & $<0.001$ & $<0.001$ & NS & NS \\
\hline
\end{tabular}

*Comparisons made with Student's $t$ test for unpaired observations. NS = Not significant.

tMean admitted over previous 14 years.

TABLE II-Mean ( $\pm S E$ of mean) serum lipid and lipoprotein concentrations in subgroups of patients

\begin{tabular}{|c|c|c|c|c|c|}
\hline & $\begin{array}{c}\text { Serum cholesterol } \\
(\mathrm{mmol} / \mathrm{l})\end{array}$ & $\underset{\substack{\text { Serum triglyceride } \\
(\mathrm{mmol} / \mathrm{l})}}{ }$ & $\begin{array}{l}\text { VLDL-triglyceride } \\
(\mathrm{mmol} / \mathrm{l})\end{array}$ & $\begin{array}{c}\text { LDL-cholesterol } \\
(\mathrm{mmol} / \mathrm{l})\end{array}$ & $\begin{array}{l}\text { HDL-cholesterol } \\
(\mathrm{mmol} / \mathrm{l})\end{array}$ \\
\hline $\begin{array}{l}\text { Men }(n=79) \\
\text { Women }(n=75)\end{array}$ & $\begin{array}{l}5.4 \div 0.12 \\
5.9 \pm 0.17 \\
\end{array}$ & $\begin{array}{l}1.2 \pm 0.08 \\
1.5 \pm 0.09 \\
\end{array}$ & $\begin{array}{l}0.4 \pm 0.05 \\
0.5 \pm 0.06\end{array}$ & 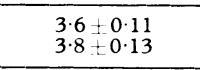 & $\begin{array}{l}1.4 \pm 0.04 \\
1.5 \pm 0.06\end{array}$ \\
\hline Significance of difference $(\mathrm{P})^{*}$ & $<0.05$ & $<0.05$ & NS & NS & NS \\
\hline $\begin{array}{l}\text { Insulin-dependent }(n=106) \\
\text { Insulin-independent }(n=48)\end{array}$ & $\begin{array}{l}5.5 \pm 0.12 \\
5.9 \pm 0.17 \\
\end{array}$ & $\begin{array}{l}1.3 \pm 0.07 \\
1.5 \pm 0.13 \\
\end{array}$ & $\begin{array}{l}0.4 \div 0.04 \\
0.6 \pm 0.09 \\
\end{array}$ & $\begin{array}{l}3 \cdot 6=0.1 \\
4 \cdot 0 \div 0.17\end{array}$ & $\begin{array}{l}1.5 \pm 0.05 \\
1.3 \pm 0.05\end{array}$ \\
\hline Significance of difference $(\mathbf{P})^{*}$ & NS & NS & $<0.01$ & $<0.02$ & $<0.005$ \\
\hline
\end{tabular}

*Assessed with Student's $t$ test for unpaired observations. NS $=$ Not significant.

Conversion: SI to traditional units-Serum cholesterol: $1 \mathrm{mmol} / 1 \approx 38.7 \mathrm{mg} / 100 \mathrm{ml}$. Serum triglyceride: $1 \mathrm{mmol} / 1 \approx 88.6 \mathrm{mg} / 100 \mathrm{ml}$. VLDL-triglyceride: as for triglyceride. LDL- and HDL-cholesterol: as for cholesterol. 
TABLE III-Prevalence of large-vessel disease in diabetics with lipid and lipoprotein concentrations in lower two quintiles (40\%) and upper two quintiles (40\%). (59 patients had vascular disease)

\begin{tabular}{|c|c|c|c|c|c|c|c|c|c|c|}
\hline & \multicolumn{2}{|c|}{ Cholesterol } & \multicolumn{2}{|c|}{ Triglyceride } & \multicolumn{2}{|c|}{ VLDL-triglyceride } & \multicolumn{2}{|c|}{ LDL-cholesterol } & \multicolumn{2}{|c|}{ HDL-cholestero } \\
\hline & No & $\%$ & No & $\%$ & No & $\%$ & No & $\%$ & No & $\%$ \\
\hline $\begin{array}{l}\text { Lower quintiles } \\
\text { Upper quintiles }\end{array}$ & $\begin{array}{l}18 \\
31\end{array}$ & $\begin{array}{l}30 \cdot 5 \\
52 \cdot 5\end{array}$ & $\begin{array}{l}19 \\
28\end{array}$ & $\begin{array}{l}32 \cdot 2 \\
47 \cdot 5\end{array}$ & $\begin{array}{l}19 \\
29\end{array}$ & $\begin{array}{l}32 \cdot 2 \\
49 \cdot 2\end{array}$ & $\begin{array}{l}15 \\
33\end{array}$ & $\begin{array}{l}25 \cdot 4 \\
55 \cdot 9\end{array}$ & $\begin{array}{l}31 \\
20\end{array}$ & $\begin{array}{l}52 \cdot 5 \\
33 \cdot 9\end{array}$ \\
\hline Significance of difference $(\mathrm{P})^{*}$ & \multicolumn{2}{|c|}{$<0.05$} & \multicolumn{2}{|c|}{ NS } & \multicolumn{2}{|c|}{ NS } & \multicolumn{2}{|c|}{$<0.002$} & \multicolumn{2}{|c|}{$<0.05$} \\
\hline
\end{tabular}

*Assessed with $\chi^{2}$ test and Yates's correction for continuity. NS = Not significant.

disease in the upper two quintiles for serum triglyceride and VLDLtriglyceride then became significantly increased above those in the lower two quintiles $(\mathrm{P}<0.05(\mathrm{n}=22 v 11)$ and $\mathrm{P}<0.01 \quad(\mathrm{n}=23 v 9)$ respectively). In addition the other relations in table III were more clearly seen. When the data were analysed with the Mann-Whitney U test the total cholesterol, total triglyceride, VLDL-triglyceride, and LDL-cholesterol concentrations were all significantly higher and the HDL-cholesterol concentration was significantly lower in the diabetics with vascular disease than in those without $(P=0.014 ; 0.006 ; 0.006$; 0.003 ; and 0.010 respectively).

The patients were then divided into those treated and not treated with insulin and into male and female groups and comparisons made of the prevalence of vascular disease and lipoprotein concentrations in each subgroup; the Mann-Whitney U test was used for analysis (table IV). In insulin-dependent diabetics higher lipid and lipoprotein

TABLE IV-Probability values for association of vascular disease with concentrations of each blood lipid. Values represent inverse associations for HDLcholesterol but positive associations for other lipids. (Mann-Whitney $U$ test)

\begin{tabular}{l|c|c|c|c}
\hline & $\begin{array}{c}\text { Insulin } \\
\text { group } \\
(\mathrm{n}=106)\end{array}$ & $\begin{array}{c}\text { Insulin- } \\
\text { independent } \\
\text { group } \\
(\mathrm{n}=48)\end{array}$ & $\begin{array}{c}\text { Men } \\
(\mathrm{n}=79)\end{array}$ & $\begin{array}{c}\text { Women } \\
(\mathrm{n}=75)\end{array}$ \\
\hline Cholesterol & 0.017 & 0.314 & 0.010 & 0.229 \\
Triglyceride & 0.031 & 0.099 & 0.039 & 0.027 \\
VLDL-triglyceride & 0.029 & 0.236 & 0.049 & 0.028 \\
LDL-cholesterol & 0.015 & 0.163 & 0.016 & 0.038 \\
HDL-cholesterol & 0.384 & 0.010 & 0.378 & 0.0003 \\
\hline
\end{tabular}

concentrations were associated with vascular disease, particularly concentrations of cholesterol and LDL-cholesterol but also of triglyceride and VLDL-triglyceride. There was no apparent relation between HDL-cholesterol and vascular disease. In the insulinindependent diabetics higher HDL-cholesterol concentrations were related to a reduced prevalence of vascular disease $(P=0.01)$ but there were no significant relations between vascular disease and the other lipid fractions. Men with higher cholesterol or LDL-cholesterol concentrations had more vascular disease than those with lower concentrations. Again triglyceride and VLDL-triglyceride concentrations were positively associated with vascular disease, but less strongly so. HDL-cholesterol in this male subgroup was not related to vascular disease, but in the women HDL-cholesterol showed a strongly negative relation to vascular disease $(P=0.0003)$. Weaker and positive associations were also seen in the women between vascular disease and triglyceride, VLDL-triglyceride, and LDL-cholesterol.

\section{Discussion}

These results suggest that vascular disease in diabetics is more likely to occur when blood lipid concentrations are raised. Furthermore, a raised LDL-cholesterol concentration showed a more pronounced relation with vascular disease than did a raised total serum cholesterol concentration.

Mean HDL concentrations in the 59 patients with vascular disease were not significantly lower than in those free of largevessel disease. Patients in the lower two quintiles for HDLcholesterol concentrations, however, had a higher prevalence of vascular complications than those in the upper two quintiles $(P<0.05)$ (table III). This inverse relation between high HDL concentrations and arterial disease has been emphasised before, ${ }^{1-5}$ and it has been suggested that HDL may be the most valuable index of the risk of coronary heart disease in the general population. ${ }^{426}$ Our findings suggest that in diabetics HDL concentrations may be less clearly related to the occurrence of atheroma than LDL concentrations.

It should also be noted that the relations between lipoproteins and vascular disease in the whole group did not extend into all the subgroups. Thus raised LDL was particularly associated with vascular disease in the men and in the subgroups of patients of either sex who were receiving insulin. In these groups there was no inverse relation between HDL concentrations and vascular disease. In patients of either sex who were insulinindependent and in all the women regardless of treatment HDL did show an inverse relation with the prevalence of atheroma.

Probably other risk factors influenced the development of large-vessel disease. Although men smoked more than women, there was no preponderance of smokers in those with vascular disease (table I). Mean diastolic blood pressure was similar in groups with and without vascular disease, although systolic pressure was significantly higher in patients with complications. Patients with vascular disease were also older and more obese. In the Framingham study diabetics who were followed up prospectively showed an increased morbidity and mortality from all cardiovascular complications. ${ }^{19}$ Diabetics in that study had higher serum cholesterol concentrations and more hypertension and were more obese than non-diabetics, but the risk factors individually or in combination were not enough to account for this increased incidence of vascular disease. Unfortunately, individual lipoprotein concentrations were not reported.

Our data suggest that there is a stronger association between vascular disease and LDL-cholesterol than HDL-cholesterol in diabetes. Although there was an inverse relation between concentrations of HDL and arterial disease it did not extend into all the subgroups. Thus there appears to be no overriding association between HDL and vascular disease in diabetics, as has been suggested for non-diabetic populations.

J P D Reckless received an Aylwen Bursary from St Bartholomew's Hospital, and D J Betteridge is the R D Lawrence research fellow of the British Diabetic Association. The excellent administrative and secretarial help of Mrs Hazel Smith is gratefully acknowledged.

\section{References}

${ }^{1}$ Castelli, W P, et al, Circulation, 1975, 52, suppl II-97.

${ }^{2}$ Miller, G J, and Miller, N E, Lancet, 1975, 1, 16.

${ }^{3}$ Rhoads, G G, Gulbrandsen, C L, and Kagan, A, New England fournal of Medicine, 1976, 294, 293.

4 Gordon, T, et al, American fournal of Medicine, 1977, 62, 707.

${ }^{5}$ Miller, N E, et al, Lancet, 1977, 1, 965.

${ }^{6}$ Nikkila, E, Scandinavian fournal of Clinical and Laboratory Investigation, 1953, 5, suppl No 8.

${ }^{7}$ Lewis, B, et al, Lancet, 1974, 1, 141.

${ }^{8}$ Berg, K, Børresen, A L, and Dahlen, G, Lancet, 1976, 1, 499.

9 Albers, J J, et al, Metabolism, 1976, 25, 633.

${ }_{10}$ Albers, J J, and Cheung, M C, Circulation, 1976, 54, suppl II-93.

${ }_{11}$ Glomset, J A, Fournal of Lipid Research, 1968, 9, 155.

${ }^{12}$ Stein, Y, et al, Biochimica et Biophysica Acta, 1975, 380, 106.

${ }^{13}$ Carew, T E, et al, Lancet, 1976, 1, 1315.

${ }^{14}$ Miller, N E, et al, fournal of Clinical Investigation, 1977, 60, 78.

15 Reckless, J P D, Weinstein, D B, and Steinberg, D, Circulation, 1976, 53, suppl II-56. 
${ }^{16}$ Liebow, I M, Hellestein, $\mathrm{H} \mathrm{K}$, and Miller, M, American Fournal of Medicine, 1955, 18, 438.

17 Keen, H, et al, Lancet, 1962, 2, 1188

18 Cohen, A M, Geriatrics, 1968, 23, 158

19 Garcia, M J, et al, Diabetes, 1974, 23, 105.

20 New, M I, et al, Diabetes, 1963, 12, 208.

${ }^{21}$ Levy, R I, and Glueck, C J, Annals of Internal Medicine, 1969, 123, 220.

${ }^{22}$ Wilson, D E, et al, Fournal of Chronic Diseases, 1970, 23, 501.

23 Ononogbu, I C, and Lewis, B, Clinica Chimica Acta, 1976, 71, 397.
${ }^{24}$ Burstein, M, Scholnick, H R, and Morfin, R, fournal of Lipid Research, 1970, 11, 583.

${ }^{25}$ Cramp, D C, and Robertson, G, Analytical Biochemistry, 1968, 25, 246 ${ }^{26}$ Miller, G J, Miller, N E, and Ashcroft, M T, Clinical Science and Molecular Medicine, 1976, 51, 475.

${ }^{27}$ Metropolitan Life Insurance Company, in Documenta Geigy, 7th edn, p 712. Macclesfield, Geigy Pharmaceuticals, 1970.

(Accepted 18 fanuary 1978)

\title{
Lung function in asthmatic children after year or more without symptoms or treatment
}

\author{
K F KERREBIJN， A C FIOOLE， R D W VAN BENTVELD
}

\begin{abstract}
Summary and conclusions
Lung function was examined in 24 children who for a year or more had not received treatment for asthma or had any asthmatic symptoms. Although clinical recovery from asthma was apparent, increased bronchial smoothmuscle tone remained present, which probably renders such children susceptible to obstructive lung disease in adult life. These children should be given guidance on treatment of their symptoms and instructed in preventive measures.
\end{abstract}

\section{Introduction}

Many doctors and patients consider that children have "grown out of" their asthma when their symptoms have disappeared and peak flow rates or spirometric values are within the normal range. Although abnormal respiratory function may be found in asthmatic people during symptom-free intervals, ${ }^{1-3}$ little is known about respiratory function in asthmatic children who have been symptom-free for a long period and are considered by everyone to be cured. We investigated respiratory function in children with a past history of asthma who had had no symptoms for 12 months or longer to see whether they were, in fact, cured.

\section{Patients and methods}

Respiratory function was measured in 24 children aged 9-16 (mean 12) years who had at some time received treatment in the outpatient department for respiratory diseases resulting from asthma. They were considered to be cured because $(a)$ for at least 12 months they had been free of cough, wheezing, and breathlessness at rest and on exertion and had not needed treatment for respiratory diseases; and $(b)$ over the past 12-18 months all three or more measurements of $\mathrm{FEV}_{1} / \mathrm{VC}$ (forced expiratory volume in one second expressed as percentage of inspiratory vital capacity) had been at least $70 \%$-that

\footnotetext{
Department of Paediatrics, Subdepartment of Respiratory Diseases, Erasmus University Medical School, Sophia Children's Hospital, Rotterdam, The Netherlands

$\mathrm{K}$ F KERREBIJN, MD, associate professor of respiratory diseases in children

A C FIOOLE, medical student

$R$ D W VAN BENTVELD, medical student
}

is, within $-2 \mathrm{SD}$ of the expected mean. $\mathrm{An} \mathrm{FEV}_{1} / \mathrm{VC}$ of below $70 \%$ is a sensitive indicator of bronchial obstruction ${ }^{45}$ and is easy to distinguish from normal values. The test is commonly used clinically and in epidemiological studies. All measurements were done on the same day between $9 \mathrm{am}$ and $1 \mathrm{pm}$, some of the children having been trained in advance. For ethical reasons we could not make comparative measurements in children without a history of asthma.

The following determinations were used in evaluating the results:

(1) Volume-constant body plethysmography (the body box; Siemens Siregnost FD 40) was used to measure total lung capacity $\left(\mathrm{TLC}_{\mathrm{Bb}}\right)$, functional residual capacity $\left(\mathrm{FRC}_{\mathrm{Bb}}\right)$, and residual volume $\left(\mathrm{RV}_{\mathrm{Bb}}\right)$. Volumes were calculated by integrating the expiratory flow through a heated pneumotachygraph (Fleisch No 31458), which is about linear up to $500 \mathrm{l} / \mathrm{min}$. The means of five to eight reliable determinations were used in each case. Measurements were taken with the patient sitting.

(2) Total lung capacity ( TLC $_{\mathrm{He}}$ ) was measured by the helium dilution method with a Mijnhardt volumograph (No 660502). The oxygen supply of this apparatus is controlled by the oxygen pressure in the helium and oxygen reservoir. Measurements were taken with the patient semirecumbent, the wash-in time being about 10 minutes. Means of duplicate measurements were used.

(3) VC, forced expiratory vital capacity (FVC), $\mathrm{FEV}_{1}$, and maximal mid-expiratory flow between $25 \%$ and $75 \%$ of FVC (MMEF) were measured with a valveless, 6 litre, waterfilled spirometer (Lode No D 53R). Measurements were taken with the patient sitting. The best of three values was used. VC was also measured in the body plethysmograph and from determinations of TLC $_{\mathrm{He}}$ and FVC with maximal expiratory flows (see below).

(4) Maximal expiratory flows were measured at $60 \% \mathrm{TLC}_{\mathrm{B}}$ $\left(\mathrm{MEF}_{60 \mathrm{TLC}}\right), 50 \%$ FVC $\left(\mathrm{MEF}_{50 \mathrm{FVC}}\right)$, and $25 \% \mathrm{FVC}\left(\mathrm{MEF}_{25 \mathrm{FVC}}\right)$ -that is, after $40 \%$ TLC, $50 \%$ FVC, and $75 \%$ FVC had been exhaled respectively. Measurements were taken sitting, outside the body plethysmograph, the child exhaling maximally through a heated pneumotachygraph. An artefact of this method, which is due to thoracic gas compression ${ }^{1}$ and affects the maximal expiratory flow curves, ${ }^{6}$ was ignored. A decrease indicated obstruction in the peripheral airways.?

All measurements were taken before and after bronchodilatation with intramuscular thiazinamium $25 \mathrm{mg}$. (Thiazinamium is a parasympatholytic drug with antihistaminic properties that causes maximal relaxation of the bronchial musculature.) The order of measurements before bronchodilatation was (3), (2), (4), and (1); after bronchodilatation this was reversed so that the $\mathrm{TLC}_{\mathrm{Bb}}$ did not increase because of swallowed air. Each series of measurements lasted about 90 minutes, and the patients rested for 15-30 minutes before and after the administration of thiazinamium.

The estimated mean values (EMV) were calculated with the regression equations of Zapletal et al. ${ }^{8}$ Accepted lower limits of the normal ranges are $80 \%$ of the EMV for TLC, VC, FVC, and FEV and $70 \%$ of the EMV for MMEF, $\mathrm{ME}_{60 \mathrm{TLC}}, \mathrm{MEF}_{50 \mathrm{FVC}}$, and $\mathrm{MEF}_{25 \mathrm{FVC}}$ - that is, about $-2 \mathrm{SD}$ of the EMV in all cases. Values for VC and FEV in healthy Dutch children ${ }^{9}$ and for MEF in Australian children $^{10}$ and a small series of healthy Dutch children investigated 